ISSN 2078-6441. Вісник Львівського університету. Серія географічна. 2013. Випуск 41. С. 70-75. Visnyk of the Lviv University. Series Geography. 2013. Issue 41. P. 70-75.

911.3

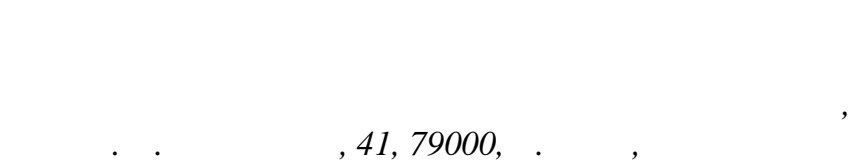

ро н лізов но історико-геогр фічні спекти індустрі ліз ції ьвівської обл. иділено чотири ет пи індустрі ліз ції т період деіндустрі ліз ції. изн чено основні причини т н слідки цих процесів. х р ктеризов но головні риси кожного з ет пів.

лючові слов : індустрі ліз ція, деіндустрі ліз ція, реіндустрі ліз ція, промисловий розвиток, промисловий комплекс, економічний з неп д.

успільн геогр фія у другій половині $\quad-$ н поч тку ст. швидко диференціюється т інтегрується із інших н укових дисциплін. епер перев ж ють дослідження в г лузях політичної, соці льної геогр фії т демогеогр фії. ізко зменшил сь кількість публік цій, присвячених геогр фії г лузей виробничої сфери: промисловості, сільського господ рств, тр нспорту. одноч с, у цих г лузях простежуються н дзвич йно скл дні процеси, у тому числі геопросторової тр нсформ ції, які недост тньо досліджують геогр фи.

різних ет п х індустрі ліз ції з хідного регіону кр їни, пит нням розвитку промисловості були присвячені пр ці . щенк, . ст вного, . угового, . робецького, . блія, . имонович, . ремчишин т ін. ст нніми рок ми н йбільше ув ги проблем м промислового розвитку кр їни приділяли . щук т . х рченко.

хідний регіон кр їни, поряд з окремими територіями ентр льно- хідної т івденної вропи, є одним з н йменш індустрі лізов них регіонів вропейського субконтиненту. ьвівщин вирізняється дещо вищим рівнем промислового розвитку серед 3 хідноукр їнських обл стей, проте ч стк промислової продукції в обл сті не перевищує $25 \%$ і тепер зн чно скоротил ся порівняно з 1990 р. [10].

кий сл бкий промисловий розвиток ьвівської обл., поряд з б г тьм іншими регіон ми кр їни, зумовлений низкою політичних т економіко-геогр фічних чинників, які, н ж ль, трив лий ч с були несприятливими для розвитку господ рств . період промислового розвитку вропи укр їнські землі були окупов ні кільком імперіями, дуже ч сто змінюв лись політичні кордони, кр їн постійно перебув л у великом сшт бних військових конфлікт х. ому коли в нглії промисловий переворот відбувся ще у V ст., у більшості кр їн хідної т ентр льної вропи - н поч тку т в середині ст., то в личині він розпоч вся лише н прикінці ст. вн слідок нещ дної експлу т ції її природних ресурсів.

роцеси індустрі ліз ції ьвівської обл. розтягнулися більш ніж н сто років, проте в регіоні т к і не було сформов но промислового комплексу, який би відповід в природно-ресурсним, демогр фічним і соці льним особливостям регіону. икон ний н ліз

овк ., 2013 
3 свідчив, що можн виділити щон йменше чотири ет пи індустрі ліз ції, як припинял ся і н віть змінюв л ся процес ми деіндустрі ліз ції.

ерший ет $n$ розпоч вся н прикінці ст. розвитком лісопильної і н фтодобувної промисловості, м сшт бного виробництв будівельних м тері лів, поступовим переходом від ремісничого до індустрі льного виробництв у легкій т х рчовій промисловості. же н поч тку ст. поч л швидко розвив тися електроенергетик т мет лообробк . ромисловість концентрув л ся перев жно в ередк рп тті ( орисл в, рогобич, трий), у ьвові т його околицях. цьому ет пі промисловість опир л сь н місцеві ресурси, тр диції т потреби н селення. ч сів польської вл ди перше місце 3 кількістю підприємств і робітників посід ли швейн і взуттєв г лузі промисловості, друге - будівельн , третє - х рчов , четверте-мет лообробн [7].

ерш світов т н ступн укр їнсько-польськ війни призвели до різкого сп ду в промисловому виробництві. стину промислових підприємств знищено, інші перев жно простоюв ли. кономічний з неп д продовжув вся до середини 1920-х років. ерев жно гр рн іч осполит зусилля з індустрі ліз ції спрямовув л н центр льні т південні р йони держ ви, личину т олинь тр ктув л як буферну зону т сировинний дод ток. ередк рп тті, крім н фти, поч ли видобув ти г з, розвив л ся н фтопереробк , н фто- і лісохімія. ост тня сировинн $6 з$ д в л змогу розвив ти різном нітні виробництв х рчової і легкої промисловості [9]. ьвів ст в великим виробником горілч них т кондитерських виробів, у середніх і м лих міст х укр їнськ коопер ція будув л невеликі підприємств 3 переробки тв ринницької продукції (“ слосоюз” т ін.). оступово н гром джув вся промисловий к піт л, формув вся к дровий потенці л, збільшув лось н дходження іноземних інвестицій. 1930-х рок х у ьвові з'явилося м шинобудув ння, одн к темпи промислового розвитку були втр чені і зн чно поступ лися попередньому періоду. прикінці 30-х років н йпотужнішими підприємств ми у ьвові вв ж ли склоз води “ ьвів” і “ еополіс”, які м ли, відповідно, 400 і 350 робітників, три шкіряні з води (“ елліс”, “ ерм т ” і “ овость”), де пр цюв ло по 200, 150 і 75 робітників. х рчовій промисловості н йбільшими були кондитерські ф брики “р нк”, “ зет” і ефлінгер , н яких, відповідно, було 485, 290 і пон д 100 робітників, консервний з вод укер - 500-600, пивов рний - 370, держ вний спиртогорілч ний чевського і спиртодріжджовий, де пр цюв ло по 100-300 робітників, і низк менших підприємств [7]. оки 1940-ві знову ст ли періодом економічного т промислового з неп ду регіону. еред промислових робітників т інженерного персон лу до 1939 р. перев ж ли поляки, великою бул ч стк євреїв, німців і укр їнський робочий кл с. сові депорт ції 1940-х років пр ктично знищили к дровий потенці л обл сті.

ругий ет $n$ прискореного промислового розвитку обл сті розпоч вся лише у 1950-х рок х. орсов н р дянськ індустрі ліз ція бул спрямов н , н с мперед, н експлу т цію природних ресурсів і використ ння дешевої сільськогоспод рської сировини. усилля вчених геологів, геогр фів, економістів були спрямов ні н дет льну інвент риз цію різних видів природних ресурсів, н с мперед мінер льних [1]. ьвівщин перетворил ся н “кр й вугілля, н фти, г зу” [3]. рім лісопильних, виникли потужні целюлозно-п перові т меблеві підприємств . озпоч л ся широком сшт бн експлу т ція гірничо-хімічної сировини: к лійних солей і сірки.

сильн колективіз ція сільського господ рств д л змогу підвищити його тов рність і змінити спеці ліз цію відповідно до з г льносоюзних потреб. икористовуючи дешеву робочу силу і з нижені т рифи н сільськогоспод рську продукцію, н ьвів- 
щині створили потужну х рчову промисловість: м'ясну, м слосироробну, цукрову, плодоовочевоконсервну. длишок трудових ресурсів сприяв т кож розвитку легкої промисловості (взуттєвої, швейної, трикот жної), м шинобудув ння т мет лообробки. еликі підприємств знову ж т ки концентрув лись у ьвові т міст х ередк рп ття, проте з'явились нові промислові центри у ок льському т икол ївському р йон х. ізном нітність природних л ндш фтів міст зумовил територі льний розвиток промисловості. к промисловий у ьвові трив лий ч с виділявся північний $\mathrm{p}$ йон, що розміщений між п горб ми озточчя н сході, ортумовою горою н з ході й простяг ється до р. олтв . од тковими чинник ми, які створюв ли відповідні умови, були близькість до з лізничної ст нції ідз мче і менш земельн рент (ця територія до 1931 р. не входил до міст ). другій половині ХХ ст. він формув вся як р йон легкої т х рчової промисловості. ут були зосереджені шкіркомбін т, л коф рбовий і г зовий з води, х рчові підприємств, зокрем, великий хлібокомбін т, м слоз вод, м'ясокомбін т, кондитерськ ф брик, рибокоптильний, пивов рний і лікерогорілч ний з води, т кож підприємств з виробництв скл, розт шув ння яких зумовлене н явністю поблизу піску (1962р. н б зі цих підприємств створено виробниче об'єдн ння “ йдуг”). еред підприємств мет лообробної промисловості виділявся інструмент льний з вод. ерев жно всі ці підприємств створені н б зі невеликих м йстерень.

ругий, з хідний, сектор промислового р йону, територія якого перев жно збіг ється з меж ми лізничного дміністр тивного р йону, був головним осередком м шинобудув ння. ретій, південний, сектор тяжіє до з лізничних ст нцій ерсенківк і книлів. кономічну основу його ст новлять підприємств електротехнічної й енергетичної промисловості (з води “скр”, ізоляторний, електропобутової п р тури) т втобусний з вод. ут зосереджен груп цегельних 3 водів (що пояснюють н с мперед н явністю сировини), т кожз вод будівельних м тері лів [7].

ідкриття нових потужних родовищ корисних коп лин у ибіру, з хст ні й ередній зії т їхнє освоєння змінили підходи до н прямів індустрі ліз ції в густоз селених обл стях хідної кр їни. о середини 1960-х років тут вже бул створен розг лужен систем 3 кл дів профтехосвіти, як могл щорічно готув ти десятки тисяч робітників. уст мереж сільських поселень і тр нспортних шляхів д л змогу орг нізув ти щоденне підвезення великої кількості робочої сили н великі промислові підприємств . ому у ьвові, рогобичі, трию, ервоногр ді, мборі й інших менших міст х обл сті споруджув ли десятки підприємств м шинобудув ння т легкої промисловості, розр хов них н дешеву і порівняно кв ліфіков ну робочу силу. е перев жно були скл д льні з води, які отримув ли комплектув льні з б г тьох республік колишнього . обто у 1970-1980-ті роки розпоч вся новий, третій, ет п індустрі ліз ції у ьвівській обл., який поляг в у розвитку високотехнологічних г лузей, і з виробництвом окремих видів продукції (телевізорів, кінескопів, втобусів, електрол мп) ьвів посід в провідні місця в . ей ет п супроводжув вся переходом до використ ння дешевих трудових ресурсів, прискореного розвитку м шинобудув ння т легкої промисловості. уже бг то підприємств ьвівщини н леж ли до військовопромислового комплексу, інші були н дзвич йно з лежними від пост ч льників через свідому політику керівництв н зосередження 6 зових виробництв н території осії. ому коли 1991 р. (ще до проголошення нез лежності кр їни) тодішнє керівництво осійської едер ції ухв лило рішення про з циклення військового виробництв лише н території , це н дзвич йно нег тивно позн чилося н промисловості ьвов й 
обл сті. ередусім зупинились велетенські промислові об'єдн ння

“ ікроприл д”, “ олярон” т інші, н кожному з яких пр цюв ло пон д 10 тис. робітників. е витрим ли конкуренції з “ зійськими тигр ми” телевізійн т р діопромисловість, т кож легк промисловість ьвівщини. оч л сь н йбільш м сшт бн деіндусmpi ліз ція обл сті, що супроводжув л сь звільненням бо т к зв ною тимч совою 3 йнятістю сотень тисяч пр цівників, які ф ктично втр тили джерел існув ння. олишні робітники ч стково повернулись у сільську місцевість, ч стково з йнялися дрібним бізнесом, головно виїх ли н 3 робітки з кордон. йгіршим н слідком цих процесів бул втр т не виробничих приміщень (які ч сто були пристосов ними) чи обл дн ння (здебільшого мор льно з ст рілого), к дрового потенці лу обл сті і поступовий з неп д престижу робітничих професій. собливо нег тивні н слідки деіндустрі ліз ція м л для невеликих міст ( овояворівськ , ового оздолу, тебник, еремишлян т ін.), де одне велике підприємство з безпечув ло добробут і більшості його мешк нців, і с мого поселення.

четвертому ет $n i$, який розпоч вся з 1990-х років, перев ж ли х рчов т легк промисловість. ідбувся сп д промисловості й обсяги виробництв зменшились утричі, вдвічі скоротил сь кількість з йнятих у цій г лузі. роте з 2000 р. поч л ся реіндустpi ліз ція обл сті, зросли темпи промислового розвитку. ише у 2005 і 2009 рр. відчувся сп д виробництв . те у 2002, 2003 і 2011 рр. промислове виробництво перевищило $110 \%$, у 2001 р. ст новило $143 \%$ від попереднього року. г лом 3 десять років (2001-2010) виробництво промислової продукції у порівняльних цін х зросло удвічі, в бсолютних цін х збільшилося у 6 р зів. н чний вплив н господ рство обл сті м ють інфляційні процеси, стрибки цін н сировину і готову продукцію н внутрішньому і світовому ринку. стк промисловості у структурі в лової дод ної в ртості колив ється від 21-23\% у 2001-2008 рр. до $19 \%$ у 2009 р. т 17,4 \% у 2010 р. [10].

ідбул ся виробнич деконцентр ція т децентр ліз ція і просторове роззосередження промислових підприємств. кщо про н лізув ти к рти промисловості в тл сі “ ьвів. омплексний тл с”, то можн поб чити, що потужні виробничі об'єдн ння були реорг нізов ні у низку дрібних бо середніх підприємств. кремі 3 води (“ ехсклоз вод”, “ ”, “ інескоп” т “ олярон”) бо повністю демонтов ні, бо пристосов ні під інші види діяльності. мість тисяч і десятків тисяч пр цівників н н йбільших підприємств х (“ віточ”, “скр ”, “ ьвівськ пивов рня”) з йнято від 500 до 1000 осіб [6].

тже, незв ж ючи н те, що процеси індустрі ліз ції у ьвівській обл сті розтягнулися більш ніж н століття, відбув лися в дуже різних політичних т економічних умов х, між різними їхніми ет п ми можн зн йти певні спільні риси. $р$ докс льно, проте н й ктивніше промисловість розвив л ся з ч сів імперських держ в, політик яких бул спрямов н н вик чув ння природних ресурсів т експлу т цію дешевої робочої сили. ндустрі ліз ція відбув л сь 3 кошти прив тного європейського к піт лу в ч си встро- горщини т держ вних к піт ловкл день у ч си . більшості г лузей промисловості не було створено з вершених комплексів. одних розвив лись добувні ст дії виробництв, в інших - 3 верш льні, тому ст н промисловості обл сті н дзвич йно сильно з леж в від ситу ції в метрополіях.

ч си, коли територія ьвівської обл. бул в скл ді молодих н ціон льних держ в, ольщі (1920-1939) т кр їни (з 1991 р.), процеси індустрі ліз ції різко призупинялися, промислове виробництво зменшув лося. е пояснюють сл бкістю місцевого промислового к піт лу, відсутністю комплексної переробки сировини, периферійним роз- 
т шув нням, непевністю політичної т економічної ситу ції. ціон льний к піт л цих кр їн концентрув вся перев жно в ст рих гірничо-мет лургійних р йон х т у столицях і певний ч с не виявляв з цік вленості до перев жно гр рних регіонів хідної кр їни. йменше економічний сп д з чіп в ті г лузі, які орієнтув лись головно н спожив ч , м ли вл сну сировинну б зу і д вні тр диції розвитку - х рчову, деревообробну, легку. кщо нині про н лізув ти ст н промисловості ьвов, то можн поб чити, що н йуспішніше пр цюють ті підприємств , які виникли ще у

ст.

\section{СПИСОК ВИКОРИСТАНОЇ ЛІТЕРАТУРИ}

1. щенко . . сновні риси геогр фії промисловості т економічне р йонув ння території з хідних обл стей / . . щенко // існ. ьвів. ун-ту. ер. геогр. - 1965. - ип. 3. - . 3-8.

2. щенко . . рик рп тський виробничий комплекс і його територі льн структур / . . щенко, . . робецький // кономічн геогр фія. - 1965. ип. $1 .-$. 26-31.

3. $c m$ вний . р й вугілля, н фти, г зу / . ст вний. - ьвів, 1961. - 157 с.

4. $x$ рченко . . $\mathrm{p}$ нсформ ційні процеси у промислових територі льних систем $\mathrm{x}$ кр їни / . . х рченко. - інниця : іп ніс, 2004. - 547 с.

5. уговой . . опросы территори льной орг низ ции промышленности кр инских рп т/ . . уговой, . . робецький, . . ымчишин, . . ыков // тери лы н уч. конф. “ ценк и использов ние природных ресурсов и р змещение производительных сил в риб лтике”. - ильнюс, 1975. - . 10-14.

6. ьвів. омплексний тл с / . блій, . тковський, . ісьт к т ін. - . : ртогр фія, 2012. - 192 с.

7. 3 рук. . ьвів у столітті. оці льно-екологічний н ліз : моногр фія / . $\quad 3$ рук. - ьвів: ім. . р нк , 2008. - 348 с.

8. блий . . ежотр слевые территори льные системы (проблемы методологии и теории) / . блий. - ьвов : ищ шк., 1976. - 200 с.

9. имонович. кономічн укр їнік . укові пр ці / . имонович. - ьвів : ім. . p HK , 2001. -432 c.

10. http://lv.ukrstat.gov.ua/ - оловне упр вління ст тистики у ьвівській обл сті.

m ття: н дійшл до ред кцї̈ 09.10.2012

доопр иьов н 21.01.2012

прийнят до друку 20.02.2013 


\title{
HISTORICAL AND GEOGRAPHICAL ASPECTS OF INDUSTRIALIZATION OF LVIV REGION
}

\section{Iryna Vovk}

Ivan Franko National University of Lviv, P. Doroshenko St., 41, UA - 79000 Lviv, Ukraine

The article analyzes the historical and geographical aspects of industrialization of Lviv region. It was distinguished four stages of industrialization and the period of deindustrialization. The main causes and consequences of these processes were identified. The main features of each stage were characterized.

Key words: industrialization, deindustrialization, reindustrialization, industrial development, industrial complex, economic decline.

\author{
рин овк \\ ввовский н цион льный университет имени в н \\ ул. . орошенко, 41, 79000, г. ьвов, кр ин
}

ро н лизиров но историко-геогр фические спекты индустри лиз ции ьвовской обл. ыделено четыре эт п индустри лиз ции и период деиндустри лиз ции. пределено основные причины и последствия этих процессов. $\mathrm{x}$ р ктеризов но гл вные черты к ждого из эт пов.

лючевые слов : индустри лиз ция, деиндустри лиз ция, реиндустри лиз ция, промышленное р звитие, промышленный комплекс, экономический уп док. 